\title{
Premises for the Politological Exploration of Sociobiology
}

\begin{abstract}
The article discusses the factors that encourage the use of the achievements of the broadly understood current of sociobiology in political science research. The guiding thesis here is the assumption that the effective use of the achievements of sociobiology for political science research may be an important factor inspiring new interpretations, explanations and forms of viewing the political sphere of social life. At the same time, it stimulates a broad view of the complexity of mutual relations between the sphere of culture and politics and biological factors. The condition for such a perspective is a departure from the reduced, genetically determinist perception of sociobiology and the understanding of culture and politics both in terms of products and determinants of the natural environment. The structure of the argument is subordinated to attempts to answer the following questions: Why is it worth being interested in using neo-evolutionist concepts to explain and describe the political sphere of social life? What is sociobiology and what theoretical assumptions can be a useful instrument of explanation in political science research?
\end{abstract}

Keywords: sociobiology, theory of politics, political theory

Attempts to research politics and related phenomena through the perspective of the biological determinants of social life have quite a rich history and considerable reference. And yet it seems that the obtained results, although interesting and inspiring a wealth of interpretations, do not find proper reflection in political science, adequate to the contemporary achievements of biology. In political research, interest in sociobiology and the dependencies of the political sphere on biological determinants still seems to be insufficient. The vast majority of definitions of politics interpret it as a consequence, manifestation or domain of cultural products of social life and human civilization development. Thomas Lemke emphasizes that this is a tendency associated with the classical meaning of politics, identified with "what goes beyond what is only sensual and bodily" (Lemke, 2010 , p. 8). In fact, in the most popular and cited ways of conceptualizing these 
notions, it is difficult to find direct references to their biological or evolutionary determinants, or even their conditions. Consistent abstraction in the ways of interpreting politics and the state from their evolutionary conditions reveals a tendency to underestimate or even completely ignore the biological factor in political science analyses, often hidden or present at the presupposition level. In this context, it is worth, at least in terms of signaling and in terms of dimensions, to indicate the premises of the politicalological exploration of the achievements of sociobiologists and to characterize the key dimensions and selected issues that can be considered in this theoretical perspective. It should also be emphasized that the understanding of sociobiology adopted here recognizes it not only as a theory, but also as a sphere or even a sphere of research. This is close to the position of Philip Kitcher (1985, p. 37), one of the most insightful researchers of the achievements of sociobiologists, who even states that, regardless of the narrowly understood sociobiological theory, this name can be equated with the general theory of evolution.

Among the many factors prompting the interest of social scientists in the achievements of biological sciences, at least two deserve a broader justification. The indisputable dynamics of the development of disciplines related to natural science fosters attempts at political science exploration of sociobiological achievements (Lewontin, 2001, pp. xxii-xxvii). It pertains especially to research in the field of biochemistry, neurobiology, genetics and phylogenetics, as well as medicine and other disciplines belonging to the canon of health sciences, contributing to revolutionary progress in the recognition of biological regularities in human life. In the opinion of many significant representatives of science, such an achievement as the reconstruction of the human genome, successful cloning procedures, reconstruction of not only the functional but also the neuronal map of the human brain, or the genetic map of nations showing the meanders of the evolution of individual ethnic groups, are undoubtedly epochal discoveries whose significance for the future of man it is hard to overestimate. One of the most spectacular achievements of modern biologists, emphasizing the level of advancement of research, was the successful cloning of animals, including the most famous sheep, Dolly. Genetic engineering and artificial intelligence experiments are not less significant and imaginative element of progress in these areas. One of the latest reports of research into the functioning of the human brain shows that scientists are successfully growing artificial neural structures called organoids, which are essentially surrogates of brain tissues that, when integrated with mechanical robots, learn to control them. This is just one of the numerous examples of research that illustrate the scale of the development of biological and medical sciences. Many new studies in the field of social sciences and humanities have already developed on this cognitively fertile and inspiring ground, conducted, for example, under the names of evolutionary psychology, cultural anthropology or cognitive science (Griffiths, 2008, pp. 393-414). 
Undoubtedly, it is also difficult for political scientists to skip or ignore this progress in knowledge, which is impressive compared to other fields of science. Supported by spectacular discoveries of the principles of formation and the rules of functioning of human physiology and metabolism, it contains hope for a new explanatory potential. It is a promise of a fresh insight, giving an opportunity to recognize existing research problems in a different context of determinants considered taking into account a new, hitherto unknown, multidimensional perspective and more complex dependencies.

However, it is worth emphasizing at this point that even with the recognition of the irregular progress in biological and medical sciences, what seems to be the most important when using the wealth of achievements of these disciplines in the field of social sciences, including political science, still remains unresolved. Despite the enthusiastic attitude and hopes related to the progress of knowledge arising from these areas, it is still impossible to answer the fundamental question concerning the processes of conversion of the brain's neural network into the content of political consciousness. We do not know the principles on which consciousness, including political consciousness, emerges from the unconscious structures of our physiology and the mechanisms of the functioning of the human body. We are not even sure if and to what extent it is the quantitative factor and neither the degree of complexity of the nervous connections of the human central nervous system that translates into a qualitative change in its functioning, i.e. consciousness (Dennett, 1991, pp. 171-221). In this context, a number of statements and conclusions formulated in the field of social sciences, including political science, are still highly speculative, concerning only possible explanatory possibilities and attempts to verify them, and not empirically confirmed correctness. In other words, the Wilsonian promise of the consensus of knowledge, its integration on the basis of a synthesis formulated in the light of the laws of nature, which at the same time enables the development of a natural science theory of society, should be considered unfulfilled at the moment.

The second, perhaps more important premise for undertaking more broadbased attempts at politicalological exploration of sociobiology is the evolution of positions belonging to the theoretical trend developed under this aegis. They continue to change under the influence of criticism and in the course of theoretical disputes, discussions or polemics, they become more and more open to interpretations that have the potential for useful applications in research in the field of social sciences and humanities. The course of this evolution also seems to be eliminating the mental barriers related to worldview commitment, which also hinder political applications of the achievements of biological sciences. To discover this potential, however, one must go beyond the perception of sociobiology in its stereotypical, superficial and highly simplified view, related to the reception of works by Charles Darwin, Herbert Spencer or early publications by Edward O. Wilson and their later apologists (Caplan, 1978). Undoubtedly, 
skepticism, or even aversion to sociobiology, is strongly associated with the criticism of genetic determinism, which is the basis for the formation of this trend. The perception of man as an instrument of the realization of impersonal driving forces encrypted in a complicated genetic system deprives him not only of autonomy, but also of the feeling of subjectivity, which is integral to self-awareness. In the opinion of critics, awareness, which is one of the pillars of human cultural autonomy and the intentionality of his actions, are the features that fundamentally distinguish man in the animal world. As a consequence, the sphere of human mental life clearly eludes Darwinian descriptions and sociobiological interpretations. This belief has been creating a mental barrier to the use of the achievements of natural science in explaining the regularities of social life since the publication of Darwin's theory.

Among the arguments of even moderate critics of the classical sociobiological approach, it is popular to say that this orientation convincingly explains social behaviour among animals, but unlawfully transfers it to the characteristics of human social behaviour. The regularities of the animal world only to a limited extent (e.g. the phenomena of nepotism, territorialism or the sanctioning of incestuous relationships) refer to human behaviour. Attempts to explain the sphere of the organization of social life, to analyze the functioning of political institutions or state structures in this perspective are not justified. According to Frans de Waal, one of the most recognizable contemporary primatologists, the barriers to self-recognition as an animal form result from the fact that each species lives in its own "Umwelt" circle of perceptions shaped by the environment during evolution (de Waal, 2016, pp. 7-13). The path of species development, specific for humans, shaped the ways of perceiving the world encoded in culture, in which the man is a unique creature and significantly grows out of the environment, including other animals. Probably Richard Dawkins, a well-known promoter of neo-evolutionism, is also right that a significant source of aversion and resistance to its acceptance are various religious doctrines, as a rule deeply opposed to rationalist forms of worldview.

It should be noted, however, that both of these researchers and thinkers, although they are among the authors of the most widely read books in this field, do not represent all contemporary sociobiological trends. Moreover, both Richard Dawkins and Frans de Waal most often represent the commercial, and therefore popular-scientific version of the position of neo-evolutionism (Kitcher, 1985, p. 47). In this version, the accessibility and attractiveness of the content of this type of book takes the form of mercantile clarity and controversy in journalistic comments and press reports. Such publications usually contain a greatly simplified interpretation of the assumptions of sociobiology and the relationship between nature and human social behaviour, becoming a grateful object for the projection of fears of sanctioning social elitism. Such practice, unfortunately, consolidates the stereotypical, and thus significantly simplified, perception of 
this perspective, becoming at the same time a source of perceiving also contemporary sociobiology as a science that reduces the explanation of social behaviour mainly to genetic determinants.

Moreover, many of these promoters of neo-evolutionism do not hide their personal worldview commitment to the interpretation they present, which inevitably places them more in the role of apologists than objective researchers. This enthusiasm of the evolutionists involved in the world outlook, especially those who treat it as the most rational and the only correct version of the interpretation of reality, may arouse justified skepticism and even aggression. The creative contribution of sociobiologists to ideological disputes, although probably effective from an economic point of view, perpetuates another stereotype of sociobiology as an ideological movement. It is a phenomenon, however, that this instrumental treatment applied to both left-wing and right-wing ideological orientations. These are primarily participants in a group formed in Boston under the name of The Sociobiology Study Group of Science for the People, including such renowned researchers as Ruth Hubbart, Stephen Jay Gould, Richard C. Lewontin and other representatives of prestigious universities (Nocoń, 2018b, pp. 351-352). Most of them represented the views typical of the New Left, but some of this criticism was shared by liberal supporters of multicultural egalitarianism and universal human rights values. The main objection concerned the justification of social inequalities and divisions, whether economic, race or gender, as natural and evolved. For left-oriented critics, sociobiology was therefore a doctrine that legitimized capitalist social relations. For liberals, on the other hand, the Darwinian vision of rivalry, conflict and war as natural elements of the selection and verification of the fittest undermined the cultural achievements and ideological foundations of liberal democracies. It was difficult to reconcile them with the ideas of multicultural integration, tolerance or equality before the law. As a consequence, both of these parties cemented the pejorative reputation of sociobiology as an ideologically engaged theoretical concept with only a superficial scientific status.

It is worth emphasizing once again that all these arguments of criticism refer primarily to the current of sociobiology, which perceives it as a new form of social Darwinism. Meanwhile, contemporary, broadly understood sociobiology, includes various positions that not only interpret the relationship between culture and nature in a different and more complex way, enabling constructive and not only critical references by representatives of social sciences and humanities, including political scientists, who understand the disjunctiveness of cultural and political relations in relation to biological factors. Recognition of many different trends currently contributing to this theoretical perspective requires in-depth studies and getting acquainted with knowledge belonging to very distant disciplines, and even scientific fields. The latter circumstance creates significant barriers in the attempts of a synoptic and objectivized view of sociobiology. We are 
dealing here with very advanced knowledge belonging to the sphere of genetics or neurobiology, which uses formalized algorithms on the one hand, and, on the other hand, the said knowledge refers to expertise in the field of physics and chemistry. An attempt to synthesize this output and its aggregation in the perspective of sociological or political assumptions, i.e. disciplines using a significantly different, interpretative language, requires painstaking effort and research results that are difficult to estimate.

In order to assess the usefulness of sociobiology for political science research, it is therefore necessary to expose a broad understanding of sociobiology, referring to the original definition of E.O. Wilson - the author of this concept, as "a systematic study of the biological foundations of all forms of social behaviour of living organisms, including humans" (Wilson, 1975, p. 2). This definition does not mean reducing these grounds to simple genetic determinism. While that was his intention at first, Wilson $(2012$, p. 9) considered correct the arguments of the criticism of the original approach and in his subsequent works this position was significantly reformed. Analysts of the legacy of sociobiology mostly agree that in later interpretations, also formulated by the followers and researchers who creatively develop this concept, the sociobiological position does not necessarily assume that all forms of behaviour are genetically determined. This is clearly emphasized by the phrase "gene-cultural coevolution" often quoted by Wilson. In fact, it suggests a two-way relationship: the complex dependence of genes on culture and culture on genes. While Wilson himself does not exclude the role of natural selection from these complex interdependencies, other interpretations find different explanations and relationships between the cultural and biological spheres of social life. In this way, the postulate formulated by Wilson (1975) becomes valid again, assuming that the evolutionary perspective should be consistently applied to everyone, and thus also to the political spheres of social life.

The achievements of disciplines referring to the broadly understood natural science and the naturalistic paradigm of scientific research have in recent decades brought serious arguments for the possibility of justifying this position. it greatly contributes to the revision of naive determinism and biological reductionism derived from the standard model of Darwinian evolution. Thanks to modern achievements, among others, in neurobiology, molecular biology and epigenetics (Dudley, Karczewski, 2013, p. 13), whose importance extends well beyond biological sciences and has important implications for all fields of human knowledge. They lead to optimistic predictions in the area of seeking a solution, or perhaps even invalidating the traditional nature versus culture dispute. Certainly, this research contributes to the resignation from attempts to reduce political behaviour only to the biological or cultural dimension.

This two-way relationship allows us to distinguish two fundamental dimensions of policy analysis in its relations with biological factors. On the one hand, 
society, through its political forms of organization and the system of institutions as forms of behaviour patterns, can be considered in terms of the effects of the principles of evolution. Politics, the processes and structures taking place within it are therefore the result of the processes of adaptation to the changing conditions of the social environment. On the other hand, politics, creating a system of institutional and normative conditions, can be analyzed in terms of factors influencing the modification of the natural environment. In other words, the political sphere of life is both the result of social evolution and its determinant.

In the latter dimension, the influence of politics and the eugenics implemented within it on the processes of evolution, references to biopolitics are often used (Lemke, 2010, p. 9). Among other research terms, this one is also defined very broadly and equated with the influence of physiology on political behaviour (Blank, Hines, 2001, p. 52). The adaptive paradigm is also known as Evolutionary Political Science. This analytical perspective also includes attempts to study political behaviour as a consequence of genetic variation within a population, i.e. inherited tendencies to certain behaviours, which therefore differ between individuals.

Explanation is an equally important premise that prompts us to try to explore concepts relating to sociobiology in political science. One of the greatest, if not the greatest strengths of theories about evolutionism may be a convincing way of explaining the natural world and the laws that govern it. The system of justifying reasons and methods of constructing explanatory argumentation and their close relations with empirical evidence make evolution one of the research paradigms - not without reason - considered by many thinkers as a model for inquiries that meet the conditions of scientific research. For this reason, the theory of evolution is considered to be one of the few ideas in history that has effectively combined natural science with social sciences and philosophy. According to one of the founders of the sociobiological movement, E.O. Wilson, the evolutionary theory may, and even should, become the theoretical basis for the integration of social knowledge. "Perhaps it is not exaggerated to suppose that sociology and other social sciences, as well as other humanities, are the last branches of biology waiting to be included in modern synthesis. So one of the tasks of sociobiology is also to reform the foundations of the social sciences in order to integrate them into modern synthesis" (Wilson, 1975, p. 15). Undoubtedly, the explanatory values of this research paradigm were important for attempts to explore it in areas of scientific research other than biology. Sociobiology has become one of the significant schools that made attempts to implement the assumptions of evolution in the field of social sciences. The predominant normative speculations and models of hypothetical-deductive explanations in the humanities and social sciences had a chance to be confronted and, consequently, verified with a concept that had direct references and solid foundations in empirical research in natural sciences. The methodology of naturalism 
and the scientific rigor characteristic of research in this field were to legitimize the scientific achievements of social sciences and humanities in a new, more convincing way. The same considerations spoke for attempts to explore the assumptions of evolutionism also in the field of political research (Peterson, Somit, 2017, pp. 4-9).

Usually, in research on the biological determinants of political behaviour, two key explanations can be distinguished. The first one, referring to the deterministic relation, is related to the specifically understood principle of causality. The second and related distinction concerns research perspectives: adaptationist or heritability. The former examines the evolutionary sources of certain behaviours, including political ones, which are therefore common to the entire species. In fact, the same phenomena can be explained both by their direct, physiological causes and by their evolutionary function, which, under the influence of selective pressure, resulted in the development and consolidation of a given phenomenon as adaptation. (Somit, Peterson, 2017).

It is worth emphasizing that on the basis of the assumptions of sociobiological concepts, relatively numerous attempts to interpret politics were made, which also implemented the evolutionary logic of explanation in political science research. An important element, or rather the foundation of this logic, is functional explanation, which, although in various forms, constitutes the explanatory core of evolutionism. In explaining the origins of social behaviour, sociobiologists have reinterpreted and changed the classical paradigm of evolutionary theory originally formulated by Darwin. Among the various interpretations, there are those that seem to be of key importance for sociobiological interpretations of politics. One of the key assumptions is that the main effect of natural selection must be to maximize reproduction. Second, the concept of fitness has been reinterpreted. The typical behaviour of a species was defined as optimal for its survival. As a consequence, there has also been increased emphasis on the adaptive nature of behaviour, which implies the possibility of more complex explanations of social behaviour. All these changes have a fundamental relationship and at the same time strongly emphasize the importance of functional explanation in sociobiological concepts of social behaviour.

The concept of function in disciplines related to biology and natural sciences is very diverse and is sometimes interpreted differently in individual theories or research approaches (Nocoń, 2018a, pp. 183, 194). In an approximate outline, we can distinguish three nodal ways of interpreting functions and the corresponding ways of explaining behaviour in the political sphere of social life. In the first place, they will be teleological interpretations of functions that are characteristic of concepts that perceive the processes of evolution in the perspective of the implementation of universal laws of nature, which are the principles of reproduction and survival. They are related to the conceptualization of politics as a sphere of competition and cooperation, optimizing the conditions of 
adaptation at the population level. Distinct from this explanation, they offer deterministic interpretations of functions that are characteristic of the interpretation of politics and politics as a result of the influence of deterministic factors, especially genes and phenotypic patterns. On the other hand, dialectical interpretations of functions make it possible to conceptualize the sphere of political behaviour in the complex perspective of the relationship between determinants and actual effects, which can be both e-functional and dysfunctional in relation to different levels of political analysis.

The ways of interpreting functions and functional explanation, integrally integrated into neo-evolutionist concepts, although not devoid of limitations and imperfections, seem to be a necessary and quite attractive supplement to the instruments of the methodological workshop of a policy researcher. Of course, genetic, structural or deterministic perspectives do not exhaust the possibilities of a comprehensive view of facts, phenomena or processes taking place in the political sphere of social life. Their explanatory utility, especially in the time macro perspective, is very limited and unconvincing. Hence, for representatives of natural sciences, they are sometimes assessed as controversial, and in radical assessments, their cognitive value is sometimes questioned. Certainly, functional models of analysis, implemented from the perspective of the assumptions of neo-evolutionism, allow to see dependencies that are impossible to identify in other theoretical approaches. They also provide important information about the determinants of political behaviour, which are elusive or irrelevant for traditional political science approaches. In the context of the modern advancement of knowledge in disciplines related to natural science, it is difficult to ignore or underestimate their explanatory potential.

This applies to at least one of the key issues for political scientists related to the factors determining collective cooperation, which is the biological foundation for all forms of political organization of people. In the sociological dimension, the issues of evolutionary determinants of collective human action were emphasized, for example, by early functionalists. This regularity was noticed, among others, by Bronisław Malinowski, who stressed that "the national principle that occurs today within the western, mechanized civilization is essentially the same as the national principle in the unfinished stone age" (Szacki, 1990, p. XVII). Nowadays, this issue is rather undisputed and it is widely accepted that the survival of the primate species was conditioned by social organization and group activity, which optimized the chances of obtaining food, maintaining safety and effective reproduction.

However, from the political science point of view, perhaps the most spectacular factor in human evolution has been the effect of collaboration and collective coordination of actions in the face of struggling with a population rival. The ability to cooperate between unrelated members of one's own species and the ability to form increasingly complex social structures have become the key 
to the unprecedented success of homo sapiens. The development of this ability was possible thanks to complex and varied adaptation processes, ranging from cognitive mechanisms such as language, abstract thinking abilities, to social institutions such as morality, religion and politics. They all arose as adaptive responses to various selection pressures from the environment, but their common denominator seems to be an attempt to solve the problem of cooperation. Examples of such a mechanism are described, among others, by Frans de Waal, who indicates that the greatest force strengthening the sense of community is, of course, hostility towards strangers. It has forced unity between the diverse individual and group interests, making us realise that nothing is more obvious to our own species than that we come together by facing our opponents. In this way, the image of the enemy also penetrates into the cultural determinants of biological evolution. In other words, political consciousness, rationally determining the interest of the community, plays the role of a biological factor on the basis of which the estimation of gains from cooperation differs from the Hamiltonian algorithm. The enemy determins and specifies the identity and the foundations of identification with the group axiology. According to de Waal: "Our evolutionary structure makes it difficult for us to identify with outsiders. We are designed to hate enemies, ignore the needs of those we hardly know, and trust no one who doesn't look like us. Even if we are mostly cooperative within our community, we become almost a different animal in the context of how we treat strangers" (de Waal, 2015, p. 299). From the macrostructural perspective, intra-group cooperation brings obvious benefits to the individual, even if viewed from the perspective of a "selfish gene": it facilitates the acquisition of resources, defense against external threats, gaining reproductive partners, and often also gives synergistic effects, impossible to achieve by individual actions (Corning, 2017, pp. 63-64).

Undoubtedly, these factors and the associated mechanisms of integration and cooperation have fundamentally contributed to the fact that politics is the sphere of life, enabling aggregation and representation of community interests both internally and externally, on the international forum. This applies not only to biological interests, but also to their aggregated forms in the form of economic, social or broadly understood cultural interests. In this way, our species has formed a separate sphere of regulation, politics, understood as the ability to mobilize groups of unrelated individuals to action over a long time and large space. The aim of politics was and is to effectively compete for resources necessary for the survival and expansion of new living spaces, development opportunities, and to ensure security for one's own group, and thus de facto basic biological rights. As a consequence, the basic political existence of the state has now become one of the basic political values of individual communities, and the possibility of establishing one's own state is usually the most important political goal of ethnic groups, especially those identifying themselves on the basis of a common national identity. 
It is worth noting at this point that it is this problem that may be the most important in the longer term, from the point of view of the importance of political science involvement in the achievements of sociobiology (Alcock, 2001). It is related to one of the most interesting, but at the same time more risky research challenges, which seems to be the question of how what can be defined as the driving force or the political subjectivity of the state is shaped. In other words, it is a question of finding an answer to the question: what factors and to what extent contribute to the correlation and integration of individual actions, their aggregation in the form of reasons of state or social interest, which become the basis for the implementation of the internal policy of the state, and define the main directions and strategies activities in the international arena. In broad terms of sociobiological assumptions, these sources could be found at three levels of social behaviour determination. The most characteristic of modern currents would be the level of genes. We are dealing here with a series of concepts and complementary empirical studies, in the light of which individual alleles of the genotype constitute the main driving force determining group interests and thus determining behaviour in the sphere of politics. From the humanistic point of view, it would probably be safer to try to recreate the driving forces at the level of the individual. However, this would mean a return to Darwin's concept and a possible revision of the principle of simple natural selection. Perhaps a phenotypic perspective would be helpful here, in the light of which, although the individual does not evolve physiologically, it can create revolutionary solutions at the phenotypic level. Political history provides ample evidence of the role of the individual in the process of fundamental political transformation. The third possibility is the prospect of looking for the sources of political subjectivity at the population level, probably towards the revitalization of Herbert Spencer's position and the controversial Wynne-Edwards theory of group selection.

Attempts to determine to what extent and how biological factors create preferences for certain political attitudes and, in a broader context, for systemic forms of organizing the state order, are no less interesting and at the same time extremely up-to-date. In investigations on this subject, there are theses concerning the relationship between the evolutionary conditions of cooperation between people and their influence on collectivist system forms, on the one hand, and the biological conditions of competition for resources that determine preferences for the formation of liberal forms of social order. These conditions can be considered both at the individual and intergroup level, and their aggregation into the sphere of political axiology. Investigations about the relationship between bioevolution and the processes of forming political behaviour or systemic forms, including democratic ones, are already an integral component of political science research. Evolutionary patterns and biological determinants of political behaviour should also be taken into account by researchers specializing in the analysis of international relations. The research on the role of the state 
and the factors determining the international strategy and policy implemented by a state organization in the network of connections with other entities on the international arena may be particularly interesting. Jerzy Ciechański, reconstructing the views of policy researchers using the evolutionary perspective of explanation, notes that democracy is a system resulting from "turbo-charging" of biological evolution by culture (Ciechański, 2016).

\section{References}

Alcock, J. (2001). The Triumph of Sociobiology. New York: Oxford University Press.

Blank, R.H., Hines, S.M. (2001). Biology and Political Science. London-New York: Routledge.

Caplan, A.L. (ed.). (1978). The Sociobiology Debate; Readings on Ethical and Scientific Issues. New York: Harper \& Row.

Ciechański, J. (2016). Czynnik biologiczny w stosunkach międzynarodowych. Warszawa: Scholar.

Corning, P. (2017). “The Evolution of Politics: A Biological Approach". In: S. Peterson, A. Somit (eds.). Handbook of Biology and Politics. Cheltenham: Edward Elgar.

Dennett, D. (1991). Consciousness Explained. New York: Little, Brown Company.

De Waal, F. (2015). Małpa w każdym z nas. Kraków: Copernicus Center Press.

De Waal, F. (2016). Bystre zwierzę. Czy jesteśmy dość mądrzy, aby zrozumieć madrość zwierząt. Kraków: Copernicus Center Press.

Dudley, J.T., Karczewski, K.J. (2013). Exploring Personal Genomics. Oxford: Oxford University Press.

Griffiths, P.E. (2008). "Ethology, Sociobiology and Evolutionary Psychology". In: S. Sarkar, A. Plutynski (eds.), A Companion to Philosophy of Biology. Oxford: Blackwells.

Kitcher, P. (1985). Vaulting Ambition. Sociobiology and the Quest for Human Nature. Cambrigde: The MIT Press.

Lemke, T. (2010). Biopolityka. Warszawa: Wydawnictwo "Sic!".

Lewontin, R.C. (2001). It Ain't Necessarily So: The Dream of the Human Genom and the Other Illusions. New York: New York Review Books.

Nocoń, J. (2018a). "Interpretacja funkcji w socjobiologicznych koncepcjach polityki”. Teoria Polityki, 4/2020.

Nocoń, J. (2018b). "Węzłowe problemy badań państwa w świetle założeń socjobiologii”. In: M. Pieraś, I. Hofman, S. Michałowski (red.). Państwo w czasach zmiany. Lublin: Wydawnictwo UMCS.

Peterson, S.A., Somit, A. (2017). "What is Biopolitics". In: S.A. Peterson, A. Somit (eds.). Handbook of Biology and Politics. Northampton: Edward Elgar Publishing.

Somit, A., Peterson, S.A. (1997). Darwinism, Dominance, and Democracy: The Biological Bases of Authoritarianism. Westport: Praeger.

Somit, A., Peterson, S.A. (2017). "The Crystal Ball, Biology, Political Science and Biopolitics". In: S.A. Peterson, A. Somit (eds.). Handbook of Biology and Politics. Northampton: Edward Elgar Publishing. 
Szacki, J. (1990). “Wstęp”. In: F. Znaniecki. Współczesne narody. Warszawa: PWN.

Wilson, E.O. (1975). Sociobiology: The New Synthesis. Cambridge: Harvard University Press.

Wilson, E.O. (2012). Konsiliencja. Jedność wiedzy. Poznań: Zysk i S-ka.

Wynne-Edwards, V.C. (1972). Animal Dispersion in Relation to Social Behavior. New York: Hafner Publishing Company. 